\title{
Characteristics of Myxobacteria Associated with Some Freshwater Fish Diseases in Japan
}

\author{
Hisatsugu WaKabaYashr and Syuzo Egusa \\ (Received May 25, 1974)
}

\begin{abstract}
Morphological, cultural and biochemical characteristics of 12 cultures of myxobacteria isolated mainly from eels with 'branchionephritis' and cyprinids with 'ulcer disease' were studied.

These organisms were gram-negative, slender rods which exhibited gliding motility on agar medium. All cultures were able to grow at $5^{\circ}, 10^{\circ}, 20^{\circ}$ and $27^{\circ} \mathrm{C}$, and tolerated a sodium chloride concentration of $1 \%$ for growth. They were uniform in their biochemical properties, though diverse in the production of cytochrome oxidase and in the reduction of nitrate. Some distinguishing features of the organisms were as follows: Degradation of starch, esculin and chitin; utilization of glucose, galactose and citrate; decomposition of tyrosine; nonproduction of hydrogen sulfide; negative reaction to Congo red. They are physiologically similar to the myxobacteria isolated from the Amerian hatchery-raised salmonids with gill disease, tail rot or other myxobacterial infections.

The histopathological features of experimentally infected eels resembled those of salmonids with 'hemorrhagic type of gill disease' described by WOOD and YASUTAKE.
\end{abstract}

Myxobacterial diseases have been poorly studied in Japan, where only columnaris disease have been reported, ${ }^{1}$ though widely studied in U. S. A. with both natural and reared populations of fishes. Included among the important myxobacterial disease well known in U.S. A. are columnaris disease caused by Chondrococcus columnaris, ${ }^{2)}$ coldwater disease due to Cytophaga psychrophila, ${ }^{3)}$ bacterial gill disease probably associated with several types of unidentified myxobacteria ${ }^{37}$ and so on. During the course of our studies on branchionephritis of eel, ${ }^{4)}$ ulcer disease of carp or its relatives ${ }^{5}$ and some cases of other diseases of unknown cause, we could often isolated a type of myxobacteria from the gills of affected fishes. The present paper reports preliminary studies on characteristic and pathogenicity of the isolates.

\section{Materials and Methods}

Materials Twelve isolates were used; six from eels, two from carps, two from crucian carps and two from goldfishes. The source of each culture investigated is shown in table 1. A strain of Chondrococcus columnaris was also included in this study for comparative purposes. Isolations of myxobacteria were carried out by using modified ANACKER and RUCKER's Cytophaga agar, which contained tryptone $0.2 \%$, yeast extract $0.05 \%$, beef extract $0.02 \%$, sodium acetate $0.02 \%$, calcium chloride $0.02 \%$, and agar $1.5 \%$. A bit of tissues taken from gills, skin or other organs was streaked onto the agar plate, which

* Dept. of Fish., Univ. of Tokyo, Tokyo, Japan (若林久䌾・江草周三: 東京大学槽学部水産学科) 
Table 1. Sources of the isolates studied

\begin{tabular}{|c|c|}
\hline $\begin{array}{l}\text { Group and } \\
\text { culture number }\end{array}$ & Location \\
\hline \multicolumn{2}{|l|}{$\begin{array}{l}\text { Branchionephritis of eel } \\
\text { (Erajin-en) }\end{array}$} \\
\hline M $26 \ldots \ldots \ldots \ldots \ldots$ Gills, eel & Yoshida, Shizuoka, Nov., 1972 \\
\hline ......Gills, eel & Yoshida, Shizuoka, Nov., 1972 \\
\hline M $40 \ldots \ldots \ldots \ldots \ldots \ldots$ Gills, eel & Yoshida, Shizuoka, Dec., 1972 \\
\hline M $41 \ldots \ldots \ldots \ldots \ldots \ldots$ Gills, eel & Yoshida, Shizuoka, Jan., 1973 \\
\hline M $56, \ldots \ldots \ldots \ldots \ldots \ldots$ Gills, eel & Yoshida, Shizuoka, Feb, 1973 \\
\hline M $81 \ldots \ldots \ldots \ldots \ldots$ Gills, eel & Yoshida, Shizuoka, May, 1973 \\
\hline \multicolumn{2}{|l|}{$\begin{array}{l}\text { Ulcer disease of cyprinids } \\
\text { (Ana-akj-byo) }\end{array}$} \\
\hline M $84 \ldots \ldots \ldots \ldots \ldots$ Skin lesion, carp & Shioda, Nagano, June, 1973 \\
\hline M $68 \ldots \ldots \ldots \ldots \ldots$ Skin lesion, goldfish & Mizumoto, Tokyo, Mar., 1973 \\
\hline ......Skin lesion, goldfish & Mizumoto, Tokyo, June, 1973 \\
\hline M $34 \ldots \ldots \ldots \ldots \ldots$ Fin, crucian carp & Lake Tega, Chiba, Nov, 1972 \\
\hline M $60 \ldots \ldots \ldots \ldots \ldots$ Fin, crucian carp & Lake Imba, Chiba, Feb., 1973 \\
\hline \multicolumn{2}{|l|}{ Diseased carp } \\
\hline$\ldots \ldots \ldots$. Gills, color carp & Chiyoda, Tokyo, Mar., 1973 \\
\hline
\end{tabular}

was then incubated at room temperature or $20^{\circ} \mathrm{C}$ for at least a week.

Morphological Characteristics Cell morphology was studied using smears from cultures and lesions. The smears were stained with LöFfLER's methylene blue. Examinations for motility and their ability to glide on agar plate were made with the phase contrast microscope by wet-mount method and the slide culture method, respectively.

Fruiting body formation and microcyst production of cultures were examined by the same methods as BULLock ${ }^{6 /}$ adopted: Fruiting body formation was obserued by inoculating the isolates onto small pieces of autoclaved fish tissue and submersing the pieces in a Iarge quantity of sterile tap water; the presence of microcysts was studieed with cultures grown in a modified DworkIN and GIBSON's medium containing casitone $1.0 \%$, magnesium sulfate $0.008 \mathrm{M}$, glycerol $0.5 \mathrm{M}$.

Environmental Characteristics The ability of isolates to grow on the modified Cytophaga agar at $5^{\circ}, 10^{\circ}, 20^{\circ}, 27^{\circ}, 32^{\circ}$ and $37^{\circ} \mathrm{C}$ were observed for 2 weeks. Tolerance to sodium chloride was determined by using the modified Cytophaga broth containing sodium chloride $0 \%, 0.5 \%, 1.0 \%, 2.0 \%, 3.0 \%$, or $4.0 \%$. Dependency of the growth on $\mathrm{pH}$ was examined with the broth of which the initial $\mathrm{pH}$ was adjusted at 5.0, 5.4, 6.0, 6.5, 7.0, $8.0,8.9,9.3$ and 9.6 by using $4 \mathrm{~N} \mathrm{HCl}$ or $4 \mathrm{~N} \mathrm{NaOH}$. In both the $\mathrm{pH}$ and sodium chloride tolerance tests, growth was determined by visible turbidity after 5 day incubation at $20^{\circ} \mathrm{C}$.

Physiological Characteristics Unless otherwise stated, methods for the various tests

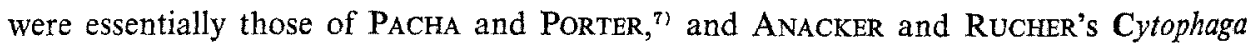
medium $^{8)}$ containing tryptone $0.05 \%$, yeast extract $0.05 \%$, beef extract $0.02 \%$ and sodium acetate $0.02 \%$ was udsd as basal medium. The presence of cytochrome oxidase was 
determined by using test paper 'Nissui'. The Congo red test consisted of flooding colonies with $0.01 \%$ aqueous solution of Congo red. Appearance of red color in the margin of colonies was considered positive. ${ }^{9}$

Sensitivity of the isolates to some antimicrobial agents was examined by the disk method on the modified Cytophaga agar. 'Mono Disk Showa' was used for the tests with polymyxin B and furazolidone. 'Tri Disk Eiken' was applied to penicillin, chloramphenicol, tetracycline, kanamycin, colistin, naldixic acid, novobiocin, sulfadimethoxine and sulfisoxasole.

Pathogenicity Attempts artificially were made to infect eel (about $150 \mathrm{~g}$ ) by adding bacteria to the aquarium water. Pure cultures of myxobacteria recently isolated from the gills of diseased eels were grown on the modified Cytophaga agar for 24 hours and were then added to the aquarium water to give a density of about $1 \times 10^{6}$ cells $/ \mathrm{ml}$. Each aquarium recieved two eels; one was intact and the gills of the other mechanichally injured by rubbing with tooth brush.

Carps, goldfishes and weatherfishes were also challenged in the same way.

\section{Results}

Morphology All of the isolates were gram-negative, slender rods which showed a swinging movement in the wet-mount preparations and exhibited gliding motility on agar. The cells were about $0.5 \mu$ wide and 2 to $5 \mu$ long in the smeares of 18 hour old cultures on agar (Fig. 1). In general, the organisms tended to become somewhat shorter at high incubation temperatures or as the culture aged.

Colonies grown on the modified Cytophaga agar were yellow-orange in color, thin, flat and spreading with irregular edges (Fig. 2). No fruiting bodies were observed after a month incubation in any of the isolates tested. Microcyst-like organisms were observed in the cultures grown in the modified Dworkin and Gibson's medium (Fig. 3). These round cells were observed to scatter among vegetative cells. They could have been spheroplasts or involution forms, because conversion of cells to microcysts was found to occur synchronously with fruiting myxobacteria. ${ }^{10)}$

Environmental Characteristics All of the isolates could grow in media with $0 \%$ to $1.0 \%$ sodium chrolide and some tolerated $2 \%$ for growth. They could grow in media the initial $\mathrm{pH}$ of which ranged 7.0 to 9.3 , and could not survive at $\mathrm{pH} 6.0$. Growth was observed at $5^{\circ}$ to $27^{\circ} \mathrm{C}$.

Physiological Characteristics With the exceptions of nitrate reduction and cytochrome oxidase production, all the test cultures showed the same biochemical reactions, which are summerized in table 2 .

Sensitivity of the isolates to antimicrobial agents is given in table 3. 
Table 2. Summary of characteristics of myxobacteria isolated from eels, carps, etc., and comparison with closely related organisms

\begin{tabular}{|c|c|c|c|c|c|c|}
\hline & \multicolumn{2}{|c|}{ This authors } & \multirow{2}{*}{$\begin{array}{l}\text { PACHA }^{81} \\
\text { Trouts, } \\
\text { etc. }\end{array}$} & \multirow{2}{*}{$\begin{array}{l}\text { Bullock } \\
\text { Trouts, } \\
\text { etc. }\end{array}$} & \multirow{2}{*}{$\begin{array}{l}\text { Chondro- } \\
\text { coccus } \\
\text { columna- } \\
\text { ris* }\end{array}$} & \multirow{2}{*}{$\begin{array}{c}\text { Cyto- } \\
\text { phaga } \\
\text { psychro- } \\
\text { phila }^{81}\end{array}$} \\
\hline & Eel & $\begin{array}{l}\text { Carp, } \\
\text { etc. }\end{array}$ & & & & \\
\hline \multicolumn{7}{|l|}{ Heat tolerance } \\
\hline Growth at $5^{\circ} \mathrm{C}$ & + & + & + & + & - & + \\
\hline Growth at $27^{\circ} \mathrm{C}$ & + & + & $\mathrm{d}$ & + & + & - \\
\hline Growth at $32^{\circ} \mathrm{C}$ & - & - & & d & + & - \\
\hline \multicolumn{7}{|l|}{$\mathrm{NaCl}$ tolerance } \\
\hline Growth in $0 \%$ & + & + & + & & + & + \\
\hline Growth in $0.5 \%$ & + & + & d & + & $\mathrm{d}$ & + \\
\hline Growth in $1.0 \%$ & + & + & $d$ & $\mathrm{~d}$ & - & - \\
\hline Growth in $2.0 \%$ & + & $d(4 / 6)$ & $\mathrm{d}$ & - & - & - \\
\hline Growth in $3.0 \%$ & - & - & $d$ & - & - & - \\
\hline \multicolumn{7}{|l|}{ Degradation of } \\
\hline Casein & + & + & + & + & + & + \\
\hline Gelatin & + & + & + & + & + & + \\
\hline Starch & + & + & + & d & - & - \\
\hline Esculin & + & + & d & & - & - \\
\hline Chitin & + & + & $\mathrm{d}$ & & - & - \\
\hline Cellulose & - & - & - & - & - & - \\
\hline Tributyrin & - & - & $\mathrm{d}$ & $\mathrm{d}$ & - & + \\
\hline \multicolumn{7}{|l|}{ Carbohydrate utilization } \\
\hline Glucose & $+w$ & $+w$ & $\mathrm{~d}$ & $\mathrm{~d}$ & - & - \\
\hline Lactose & - & - & $d$ & & - & - \\
\hline Galactose & $+w$ & $+w$ & $\mathrm{~d}$ & & - & - \\
\hline Sucrose & - & - & d & & - & - \\
\hline Nitrate reduced & $d(3 / 6)$ & $d(4 / 6)$ & $\mathrm{d}$ & $\mathrm{d}$ & $\mathrm{d}$ & - \\
\hline Hydrogen sulfide produced & - & - & d & - & + & - \\
\hline Tyrosine decomposed & + & + & d & $\mathrm{d}$ & - & + \\
\hline Citrate utilized & + & + & $\mathrm{d}$ & & - & - \\
\hline Indole produced & - & - & - & & - & - \\
\hline Catalase produced & + & + & + & + & + & + \\
\hline Cytochrome oxidase produced & $d(4 / 6)$ & $\mathrm{d}(3 / 6)$ & $d$ & - & + & - \\
\hline \multicolumn{7}{|l|}{ Lysis of dead bacterial cells } \\
\hline Escherichia coli & + & + & + & + & + & + \\
\hline Congo red test & - & - & & & + & \\
\hline
\end{tabular}

* This authors

$+=$ positive; $+\mathrm{w}=$ weakly positive; $-=$ negative; $\mathrm{d}=$ diverse; $(\mathrm{l})=$ Expressed as number of cultures positive divided by number of cultures tested.

Pathogenicity One of the two attempts to infect eels with the myxobacteria was successful (Table 4), though challenge tests with carps, goldfishes and weatherfishes were unsuccessful. The experimentally infected eels displayed the essentially same symptons as the naturally occurred cases. They became gradually inactive without any externally visible lesions except for the gill, which was characterized grossly by many apparent minute hemorrhages in the gill filaments. 
Table 3. Sensitivity of the isolates to antimicrobial agents (Sensitivity Disks 'EIKEN' \& 'SHOWA')

\begin{tabular}{lcccc}
\hline \multirow{2}{*}{ Antimicrobial agents } & Sensitive & Resistant \\
\cline { 2 - 5 } \cline { 2 - 5 } & +++ & ++ & + & - \\
\hline Penicillin & 0 & 0 & 0 & 12 \\
Chloramphenicol & 0 & 0 & 2 & 10 \\
Tetracycline & 0 & 11 & 1 & 0 \\
Kanamycin & 0 & 0 & 0 & 12 \\
Colistin & 0 & 0 & 0 & 12 \\
Nalidixic acid & 12 & 0 & 0 & 0 \\
Novobiocin & 1 & 9 & 2 & 0 \\
Polymyxin B & 0 & 0 & 0 & 12 \\
Sulfadimethoxine & 1 & 0 & 2 & 9 \\
Sulfisoxasole & 0 & 7 & 5 & 0 \\
Furazolidone & 0 & 2 & 7 & 3 \\
\hline
\end{tabular}

\section{Discussion}

In this paper we demonstrated that a myxobacterium was associated with some freshwater fish diseases in Japan. On the basis of its cultural and physiological properties it is very similar to the isolates from the salmonids with bacterial gill disease, tail rot or other diseases, ${ }^{6)}$ and also resembles some of the nonpathogenic species from the body surface of freshwater fish ${ }^{7}$ (Table 2), though there is no completely identical type among them. If the observation of microcysts in, the test cultures is valid, they may be identified as a member of the genus Sporocytophaga. But the taxonomic position of the isolate must be the subject of future study as it is now debatable whether myxobacteria isolated from fishes, including Chondrococcus columnaris, be able to produce the true microcyst or not. ${ }^{11}$

The gill lesions of the experimentally infected eels showed very interesting histopathological features. In such acute cases as in the aquaria $\# 4$ and $\# 5$ (Table 4) a large

Table 4. Pathogenicity tests with the isolates to pond-cultured eels.

\begin{tabular}{|c|c|c|c|c|c|c|c|}
\hline Test & $\begin{array}{l}\text { Aquarium } \\
\text { number }\end{array}$ & $\begin{array}{l}\text { Culture } \\
\text { number }\end{array}$ & $\begin{array}{c}\text { Density } \\
\text { (cells/ml) }\end{array}$ & $\begin{array}{l}\text { Water } \\
\text { temp. } \\
\left({ }^{\circ} \mathrm{C}\right)\end{array}$ & $\begin{array}{l}\text { Number } \\
\text { of fish } \\
\text { tested }\end{array}$ & $\begin{array}{l}\text { Number } \\
\text { of fish } \\
\text { died }\end{array}$ & $\begin{array}{l}\text { Lethal } \\
\text { time } \\
\text { (days) }\end{array}$ \\
\hline & 1 & (control) & 0 & 10 & 2 & 0 & survived \\
\hline \multirow[t]{2}{*}{ No. 1} & 2 & M26 & $1.5 \times 10^{6}$ & 10 & 2 & 2 & $10 \& 12^{*}$ \\
\hline & 3 & M27 & $1.0 \times 10^{6}$ & 10 & 2 & 1 & $14 \&$ survived \\
\hline \multirow[t]{3}{*}{ Nov. 23-Dec. 14} & 4 & M26 & $1.5 \times 10^{6}$ & 20 & 2 & 2 & $2 * \& 3$ \\
\hline & 5 & M27 & $1.0 \times 10^{6}$ & 20 & 2 & 2 & $2 * \& 2$ \\
\hline & & & & & & & $\begin{array}{l}\text { Myxobacteria } \\
\text { in aquarium } \\
\text { (Dec. 9) }\end{array}$ \\
\hline No. 2 & 6 & M26 & $1.3 \times 10^{6}$ & 15 & 2 & 0 & + \\
\hline \multirow[t]{2}{*}{ Nov. 29-Dec. 14} & 7 & M27 & $1.0 \times 10^{6}$ & 15 & 2 & 0 & + \\
\hline & 8 & M27 & $1.3 \times 10^{6}$ & 20 & 2 & 0 & + \\
\hline
\end{tabular}

* Moribund fish were sacrificed for histological examinations. 
number of slender, rod shaped bacteria were observed on the surface of the lamellae, and part of the capillaries expanded into globose masses of blood (Fig. 4) which gave the gills a gross appearance of minute hemorrhages in its filaments. In such chronical cases as in the aquaria $\# 2$ and $\# 3$, in addition to a congestive gross appearance the occurrence of remarkable hyperplasia was observed, and myxobacterial colonies were occasionally found in a vacant space of the fused lamillae (Fig. 5). It was noticiable that these gill lesions resembled rather to those of 'hemorrhagic gill disease' of hatchery-raised fingerling salmonids ${ }^{12 y}$ than those of 'bacterial gill desease', especially in the acute cases.

\section{References}

1) H. WaKabayashi and S. Egusa: This Bull, 32, 1015-1022 (1966), (in Japanese).

2) E. J. Ordal and R. R. Rucker: Proc. Soc. exp. Biol. Med., 56, 15-18 (1944).

3) A. F. Borg: Wildlife Disease No. 8, 85 p. (1960).

4) S. Egusa: Fish Pathol., 5, 51-66 (1970), (in Japanese).

5) T. MryazAKI and S. EguSA: ibid., 7, 115-121 (1973), (in Japanese).

6) G. L. Bul ock: Tech. Paper No. 80, 30 p. (1972).

7) R. E. PACha and S. Porter: Appl. Microbiol., 16, 1901-1906 (1968).

8) R. L. ANACKER and E. J. ORdAL: J. Bact., 78, 25-32 (1959).

9) J. L. Johnson and W. S. Chilton: Science 152, 1247-1248 (1966).

10) M. Dworkin and H. Voelz: J. gen. Microbiol, 28, 81-85 (1962).

11) T. G. Mitchell, M. S. Hendrie and J. M. Shewan: J. appl. Bact., 32, 40-50 (1969).

12) E. M. Wood and W. T. Yasutake: Prog. Fish-Cult., 19, 7-13 (1957). 


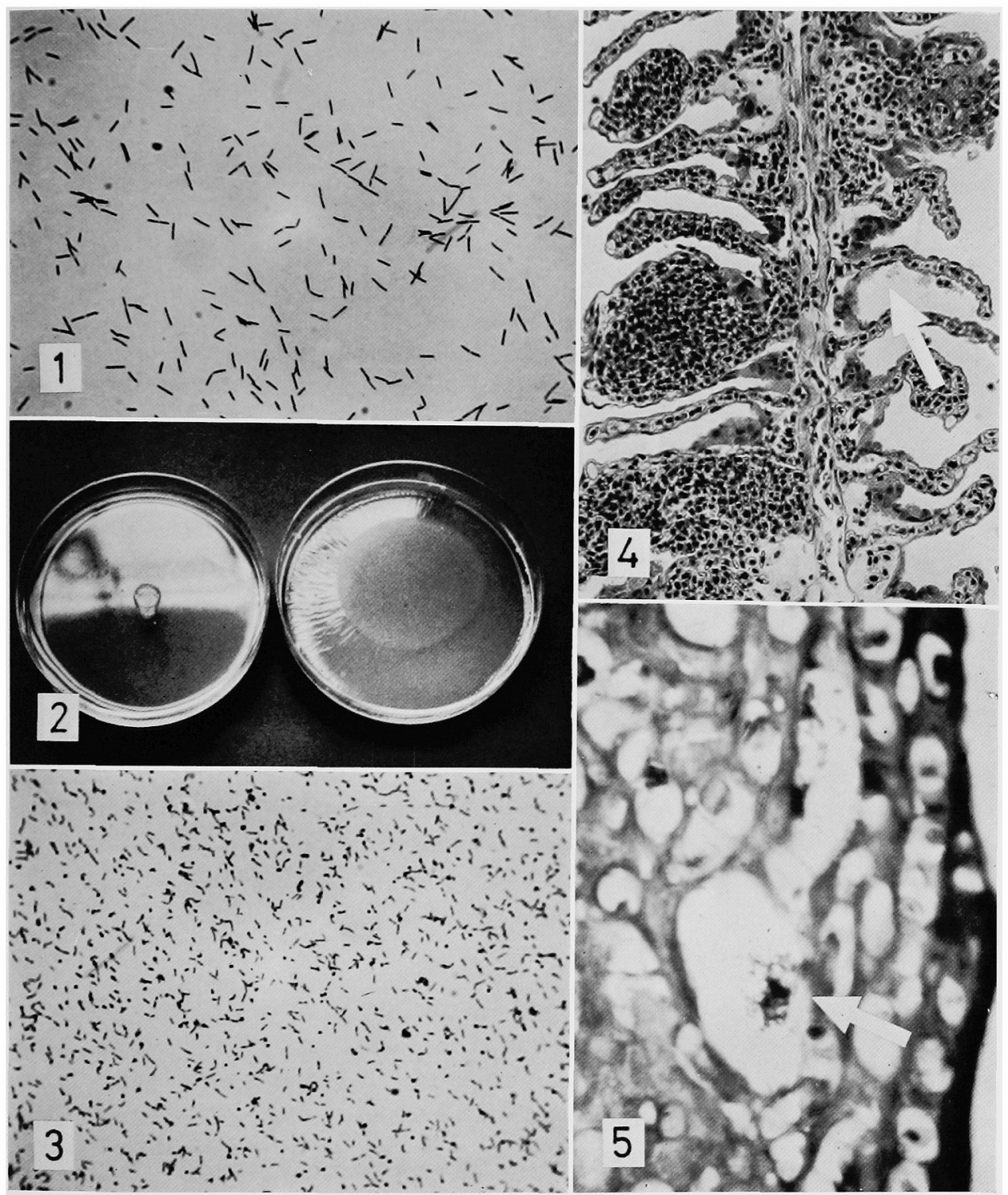

Fig. 1. Eighteen hour old culture on modified ANACKER and OrDAL's Cytophaga agar (stained with LÖFFLER's methylene blue). $\quad \times 1200$

Fig. 2. Comparison of the colonies between the myxobacteria isolated from 'branchionephritis' (right) and Chondrococcus columnaris (left), grown five days on the modified Cytophaga agar after spotting inoculation.

Fig. 3. Ten day old culture on modified Dworkin and Gibson's medium showing vegetative cells and what appear to be microcysts (stained with LöFFLER's methylene blue). $\quad \times 1200$

Fig. 4. Gill lesion of the experimentally infected eel. The myxobacteria are on the lamellae (arrow), and the capillaries expand into globose masses of blood (stained with hematoxylin and eosin). $\times 250$

Fig. 5. A mass of the myxobacteria (arrow) shut in a vacant space of the fused lamellae (stained with GIEMSA's stain). $\quad \times 600$ 